\title{
Determinants of Operational Efficiency of Microfinance Institutions in Bangladesh
}

\author{
Mohd. Abdur Rahman ${ }^{1} \&$ Ahmad Rizal Mazlan ${ }^{2}$ \\ ${ }^{1}$ In-House Multimedia Academy, G\&M Floor, Bangunan Yee Seng, 15 Jln Raja Chulan, Kuala Lumpur, \\ Malaysia \\ ${ }^{2}$ School of Economics, Finance \& Banking, Universiti Utara Malaysia, Sintok, Kedah, Malaysia \\ Correspondence: Mohd. Abdur Rahman, In-House Multimedia Academy, G\&M Floor, Bangunan Yee Seng, 15 \\ Jln Raja Chulan, 50200, Kuala Lumpur, Malaysia. Tel: 60-3-2070-2819. E-mail: rahmanshaikot@gmail.com
}

Received: April 25, 2014 Accepted: August 18, 2014 Online Published: October 30, 2014

doi:10.5539/ass.v10n22p322

URL: http://dx.doi.org/10.5539/ass.v10n22p322

\begin{abstract}
This paper investigates the performance of operational self-sufficiency and its determinants of Microfinance Institutions (MFIs) and compared their positions in Bangladesh. The study used secondary quantitative data from the MIX market website where containing information from financial statements from the MFIs operating in Bangladesh. Toward the achievement of its objectives the study used descriptive statistical and financial ratio analysis techniques as well as econometric technique on the several performance indicators standardized by CGAP to measure of MFIs performance. The multiple regression technique used to measure the determinants of operational self-sufficiency to justify with yield on gross loan portfolio (nominal), cost per borrower, average loan balance per borrowers, age of MFIs, and number of active borrowers and operating expense ratio of MFIs in Bangladesh. The multiple regression output revealed that most of the MFIs are operational self-sufficiency to operate their operations in this region. However, study recommended for policy considerations of the successful and effective operation of microfinance programs through simplify of distribution of loan, improve yield on gross loan portfolio, personnel productivity and reduces of borrowing fund from the donors, reducing operating cost, utilize resources to generate financial revenue and focused on increase of value of their total assets in Bangladesh.
\end{abstract}

Keywords: microfinance, microfinance institutions (MFIs), operational self-sufficiency and Bangladesh

\section{Introduction}

The Microfinance Institutions (MFIs) target the poor through innovative approaches, which include group lending, progressive lending, regular repayment schedules, and collateral substitutes (Thapa, 2007). The sustainable operational growth is essential for each of MFIs, to continue their operation smoothly. But previous studies in different countries have revealed mixed results with regards to the efficiency and financial sustainability of the MFIs. Gopal et al. (2011) examined the outreach and sustainability of microfinance institutions in the district of Assam, India. Analysis through various financial performance indicators such as Operational Self Sufficiency (OSS), Financial Self Sufficiency (FSS), Subsidy Dependence Index (SDI) and Subsidy Dependence Ratio (SDR) were conducted. He found that although the MFIs reached a large number of clients, analysis indicates that MFIs are still financially not self-sufficient which is reflected by a number of calculated indicators.

In a similar study, Martinez-Gonzalez (2008) also capitalized that, most MFIs have been more efficient in pursuing sustainability but fall short of achieving the breath of outreach to the targeted poor people in the country Martinez-Gonzalez (2008). However, Bayeh (2012) identifies factors affecting financial sustainability of MFIs in Ethiopia. The study found that microfinance breadth of outreach, depth of outreach, dependency ratio, and cost per borrower significantly affect the financial sustainability of microfinance institutions in Ethiopia. However, the microfinance capital structure and staff productivity have an insignificant impact on financial sustainability of MFIs in Ethiopia during the period of study. Moreover, other studies also indicate that there is a positive relationship between MFI efficiency and domestic financial development (Hermes, Lensink, \& Meesters, 2009). 
Thapa (2007) also compared the outreach of Bangladesh MFIs with those in other countries. Several other studies examined the level of financial sustainability and outreach as a case study in certain MFIs from Bangladesh. Nonetheless, no study has covered all MFIs in Bangladesh. In addition, several other studies have examined the level of financial sustainability and outreach as a case study in certain MFIs from Bangladesh. However, no study has covered all MFIs in Bangladesh. Based on the existing gap in previous researches, this study will make an attempt to fill that gap by measuring operational self-sufficiency and determining the determinants of operational of microfinance institutions (MFIs) in Bangladesh.

\section{Literature Review}

Annim, S. K. in 2012 tested two hypotheses; first, they argued that there is a trade-off between the social objectives of MFIs and their financial efficiency and secondly, they asserted complementarity between the external environment and MFIs' social efficiency. The study showed that financialy efficient MFIs failed to reach out to poorer clients; on the other hand, socialy efficient MFIs reached out to poorer clients. They also observed that bureaucracies in property registration and a lack of credit information adversely affected the social efficiency of MFIs. The research recommended that the effective role of external institutions and the removal of information barriers are important for reducing poverty through microfinance intervention (Annim, 2012). Moreever, examined by Arnone, M., C. B. Pellegrini, et al. in 2012, presents an empirical analysis of the operational efficiency of microfinance institutions. The analysis showed that operating costs and efficiency are negatively related. It pointed out that operating costs are less when institutions give high focus on traditional financial aspects of commercial banking, thereby improving their efficiency, and enhancing the development of the sector and the quality of offered services. Successively, the study tried to figure out the effect of these factors in different geographical regions. Finally, the study highlighted the importance of various legal and organizational frameworks and macro-governance features (Arnone, Pellegrini, Messa, Pellegrini, \& Sironi, 2012).

Bassem, B. S. in 2008 by applying the non-parametric Data Envelopment Analysis (DEA) method with all the limitations where error could cause significant problems, investigated the efficiency of 38 Microfinance institutions in the Mediterranean region. Results found that eight institutions are relatively efficient, and have a notable level of average efficiency and a potential of evolution while being referent to their technical efficiency. The survey ended by proposing that the size of the MFIs has a negative effect on their efficiency since the MFIs of medium size are more efficient than the eminent (Bassem, 2008). However, Gregoire, J. R. and O. Ramírez Tuya in 2006 analyzed the efficiency of Microfinance Institutions (MFIs) in Peru by estimating a stochastic cost frontier. The main findings of the study resolved that MFIs with the largest assets tend to post the highest efficiency levels, and that MFIs operating in less concentrated markets tend to be more efficient. Thus, the cost efficiency of MFIs is affected by average loan size, proportion of net assets, financial sufficiency, financial leverage, business experience and proportion of farm loans (Gregoire \& Tuya, 2006).

Gutiérrez-Nieto, B., C. Serrano-Cinca, et al. in 2007 analyzed Microfinance Institutions (MFIs) as special financial institutions; they have both a social nature and a for-profit nature.This study used a data envelopment analysis (DEA) approach to measure the efficiency of MFIs. The results revealed that MFIs efficiency can be explained by means of four principal components of efficiency, and by this way, the differences between the DEA scores can be understood. Moreover, it has shown that there are country effects on efficiency; and effects that depend on non-governmental organization (NGO)/non-NGO status of the MFI (Gutiérrez-Nieto, Serrano-Cinca, \& Molinero, 2007). In the same way, in 2009, Gutiérrez-Nieto, B., C. Serrano-Cinca, et al. asserted that microfinance institutions (MFIs) are a special case in the financial world and it has a double financial and social role and needs to be efficient at both. The study measured the efficiency of MFIs in relation to financial and social outputs using data envelopment analysis. They added two indicators of social performance: impact on women and a poverty reach index. The observation studied the relationship between social and financial efficiency, and the relationship between efficiency and other indicators, such as profitability. Other aspects studied are the relation between social efficiency and type of institution Non-Governmental Organization (NGO), non-NGO, and the importance of geographical region of activity. The findings reveal the importance of social efficiency assessment (Gutiérrez-Nieto, Serrano-Cinca, \& Molinero, 2009).

Hartarska, V. and R. Mersland in 2012 evaluated the effectiveness of several governance mechanisms on microfinance institutions' (MFI) performance. The study explored the impact of measurable governance mechanisms on the individual efficiency coefficients. The results indicated that efficiency increases with a board size of up to nine members and decreases after that. MFIs in which the CEO chairs the board and those with a larger proportion of insiders are less efficient. Moreover, the study didn't find consistent evidence for the effect of competition, but it found weak evidence that MFIs in countries with mature regulatory environments reach 
fewer clients, while MFIs regulated by an independent banking authority are more efficient. The evidence recommended that donors' presence on the board is not beneficial (Hartarska \& Mersland, 2012). Furthermore, Hartarska, V., X. Shen, et al. in 2013 evaluated the efficiency of microfinance institutions (MFIs) using a structural approach which also captures institutions' outreach and sustainability objectives. The study estimated economies of scale and input price elasticities for lending-only and deposit-mobilizing MFIs using a large sample of high-quality panel data. The outcomes confirm that improvements in efficiency can come from the growth or consolidations of MFIs, as they find substantial increasing returns to scale for all but profitability-focused deposit-mobilizing MFIs. It also supported the existence of a trade-off between outreach and sustainability (Hartarska, Shen, \& Mersland, 2013).

Hermes, N., R. Lensink, et al. in 2011 used stochastic frontier analysis to examine whether there is a trade-off between outreach to the poor and efficiency of microfinance institutions (MFIs). Findings resolved convincing evidence that outreach is negatively related to efficiency of MFIs. More specifically, the observation found that MFIs that have a lower average loan balance (a measure of the depth of outreach) are also less efficient. Moreover, those MFIs that have more women borrowers as clients (again a measure of the depth of outreach) are less efficient. These results remain robustly significant after having added a number of control variables (Hermes, Lensink, \& Meesters, 2011). On the other hand, in 2011, Hudon, M. and D. Traca used an original database of rating agencies; this study gave empirical evidence on the impact of subsidy intensity on the efficiency of Microfinance Institutions (MFIs). Findings resolved that subsidies have had a positive impact on efficiency, in the sense that MFIs that received subsidies are more efficient than those that do not. However, it also found that subsidization beyond a certain threshold renders the marginal effect on efficiency negative. Moreover, marginal cut on subsidy intensity would increase their efficiency (Hudon \& Traca, 2011).

\section{Methodology}

The present study used descriptive, econometrics statistical, and financial ratio analysis techniques on the secondary data of existing selected MFIs in Bangladesh. The secondary data of all selected MFIs in Bangladesh was extracted from the prominent microfinance online database, Mix Market (MIX, 2013) from the year of 2005 to 2011. There are five MFIs that have been selected from the Bangladesh. The selection of MFIs has been done based on the highest number of active borrowers in the Bangladesh.

Table 1. The distribution of top MFIs in BD by the number of borrowers

\begin{tabular}{ll}
\hline Name of top MFIs in BD & No. of Borrowers \\
\hline Grameen Bank & 6710000 \\
BRAC & 4193218 \\
ASA & 4181690 \\
BURO Bangladesh & 850792 \\
TMSS & 574981 \\
\hline
\end{tabular}

Sources: (Mixmarket, 2013)

Table 2. The distributions of the efficiency measurement indicators and ratios

\begin{tabular}{ll}
\hline Efficiency (\%) & \\
\hline Operating Expenses/Loan Portfolio & Operating Expense/Average Gross Loan Portfolio \\
Personnel Expenses/Loan Portfolio & Personnel Expense/Average Gross Loan Portfolio \\
Average Salary/GNI per capita & Average Personnel Expense/GNI percapita \\
Cost Per Borrower & Operating Expense/Average Number of Active Borrowers \\
Cost Per Loan & Operating Expense/Average Number of Loans Outstanding \\
\hline
\end{tabular}

Sources: Adopted from (CGAP, 2003)

Operating expense ratio is the most commonly used efficiency indicator for MFIs that includes all administrative and personnel expense. MFIs that provide smaller loans will compare unfavorably to others, even though they may be serving their target market efficiently. Likewise, MFIs that offer savings and other services will also compare unfavorably to those that do not offer these services, if gross loan portfolio is used as the denominator. Cost per borrower provides a meaningful measure of efficiency by showing the average cost of maintaining an 
active borrower. Since the size of the loans is not part of the denominator, institutions with larger loans do not automatically appear more efficient, as is the case with the operating expense ratio.

Moreover, multiple regression models have been used to measure of determinants of financial self-sufficiency of microfinance institutions (MFIs) in Bangladesh. To measure the predictor variables of financial self-sufficiency, seven measures are used as independent variables which were extracted from Woldeyes in 2012 (Woldeyes, 2012), namely Age of MFIs, Cost per Borrower, Liquidity Ratio, Number of Active Borrowers, Operating Expense Ratio and Yield on Gross loan Portfolio (Nominal).

Table 3. Description of dependent variables

\begin{tabular}{ll}
\hline Variable Name & Measurement Formula \\
\hline Financial Self-Sufficiency & Adjusted Financial revenue/(Financial expense + Loan loss provision + \\
(FSS) & Operating expenses + Expense Adjustment) \\
$\begin{array}{l}\text { Operational Self-Sufficiency } \\
\text { (OSS) }\end{array}$ & Financial revenue/(Financial expense+ Impairment losses + Operating expenses) \\
\hline
\end{tabular}

Sources: (Woldeyes, 2012)

Table 4. Description of independent variables

\begin{tabular}{|c|c|c|c|}
\hline S.N & Variables Standard Name & Description & $\begin{array}{l}\text { Variable name } \\
\text { regression model }\end{array}$ \\
\hline 1 & Age of MFIs & Age of MFIs since their establishment & AGE \\
\hline 2 & Cost Per Borrower & $\begin{array}{l}\text { Adj. Operating Expense/Adj. Av. No. of } \\
\text { Active Borrowers }\end{array}$ & $\mathrm{CPB}$ \\
\hline 3 & Number of Active Borrowers & $\begin{array}{l}\text { Number of active borrowers with loans } \\
\text { outstanding }\end{array}$ & $\operatorname{lnNAB}$ \\
\hline 4 & Operating Expense Ratio & $\begin{array}{l}\text { The ratio of operating expense to the gross } \\
\text { loan portfolio }\end{array}$ & OER \\
\hline 5 & $\begin{array}{l}\text { Yield on Gross loan Portfolio } \\
\text { (Nominal) }\end{array}$ & $\begin{array}{l}\text { Adjusted financial revenue from Loan } \\
\text { Portfolio/Adj. average GLP }\end{array}$ & YIELD \\
\hline 6 & $\begin{array}{l}\text { Average Loan Balance per } \\
\text { Borrowers }\end{array}$ & Adj. GLP/Adj. Number of Active Borrowers & $\ln A L B P B$ \\
\hline 7 & Debt to Equity Ratio & Adj. Total Liabilities/Adj. Total Equity & DER \\
\hline 8 & Personnel Productivity Ratio & $\begin{array}{l}\text { The expense incurred for personnel per the } \\
\text { loan portfolio }\end{array}$ & PPR \\
\hline 9 & Size of MFI & Total Asset of MFI & SIZE \\
\hline
\end{tabular}

Sources: (Woldeyes, 2012)

Regression Model for Operational Efficiency of MFIs:

$$
\begin{array}{r}
\text { OSSit }=\alpha i+\beta 1 \text { YIELDit }+\beta 2 \text { LnSIZEit }+\beta 3 \text { PPRit }+\beta 4 \text { DERit }+\beta 5 \text { CPBit }+\beta 6 \text { ALBPBit }+\beta 7 \text { LnAGEit }+ \\
\beta 8 \text { LnNABit } \beta 9 \text { OERit }+\varepsilon i t
\end{array}
$$

Where: OSS it is the operational self-sufficiency ratio of microfinance $i$ at time $t$ (which is the dependent variable); $\alpha \mathrm{i}$ is a constant term; $\beta$ measures the partial effect of independent or explanatory variables in period $t$ for the unit $\mathrm{i}(\mathrm{MFI}) ; \mathrm{X}$ it are the explanatory variables as described in the above table; and $\varepsilon$ it is the error term. The variables, both dependent and independent, are for cross-section unit $\mathrm{i}$ at time $\mathrm{t}$, where $\mathrm{i}=$ MFI ( 1 to $\mathrm{n})$, and $\mathrm{t}$ $=1$ to 9 .

\section{Findings and Discussion}

\subsection{Operational Self-Efficiency of MFIS}

\subsubsection{ASA Efficiency over the Period of 2005-2011}

Table 5 shows the distribution of average efficiency of ASA over the period of 2005-2011. The study has found that the value for operating expense per loan portfolio is 0.11639 with the ratio of personnel expense per loan portfolio turning out at 0.10093 accordingly. Meanwhile average salary to per GNI per capita stands at 3.47857, while cost per borrower and cost per loan is valued at 10.1084 and 10.0884 , respectively. 
Table 5. Distribution of efficiency of ASA in Bangladesh (average value from 2005 to 2011)

\begin{tabular}{llllllllll}
\hline Indicators & & \multicolumn{2}{c}{ Efficiency Of ASA } & & & \multicolumn{2}{c}{ Average } \\
& & 2005 & 2006 & 2007 & 2008 & 2009 & 2010 & 2011 & \\
\hline $\begin{array}{l}\text { Operating } \\
\text { Portfolio }\end{array}$ & Expenses/Loan & 0.0849 & 0.0944 & 0.1125 & 0.1506 & 0.1283 & 0.1313 & 0.1127 & 0.11639 \\
$\begin{array}{l}\text { Personnel } \\
\text { Portfolio }\end{array}$ & Expenses/Loan & 0.073 & 0.0825 & 0.0938 & 0.1318 & 0.1123 & 0.1153 & 0.0978 & 0.10093 \\
$\begin{array}{l}\text { Average Salary/GNI per capita } \\
\text { Cost Per Borrower }\end{array}$ & 2.88 & 3.09 & 3 & 4.39 & 3.83 & 3.87 & 3.29 & 3.47857 \\
Cost Per Loan & 5.57 & 5.6603 & 7.0848 & 10.9908 & 11.9434 & 15.32 & 14.1895 & 10.1084 \\
\hline
\end{tabular}

(Source: MIX Market database, 2013)

\subsubsection{BRAC Efficiency over the Period of 2005-2011}

Table 6 shows the distribution of average efficiency of BRAC over the period of 2005-2011. The study found that the value for operating expense per loan portfolio is 0.12651 with the ratio of personnel expense per loan portfolio turning out at 0.10951 accordingly. Meanwhile, average salary to per GNI per capita stands at 4.18714 as well as cost per borrower and cost per loan is valued at 11.2912 and 11.0252, respectively.

Table 6. Distribution of efficiency of BRAC in Bangladesh (average value from 2005 to 2011)

\begin{tabular}{|c|c|c|c|c|c|c|c|c|c|}
\hline \multirow[t]{2}{*}{ Indicators } & & \multicolumn{7}{|c|}{ Efficiency of BRAC } & \multirow[t]{2}{*}{ Average } \\
\hline & & 2005 & 2006 & 2007 & 2008 & 2009 & 2010 & 2011 & \\
\hline $\begin{array}{l}\text { Operating } \\
\text { Portfolio }\end{array}$ & Expenses/Loan & 0.15 & 0.1322 & 0.1466 & 0.1106 & 0.101 & 0.1165 & 0.1287 & 0.12651 \\
\hline $\begin{array}{l}\text { Personnel } \\
\text { Portfolio }\end{array}$ & Expenses/Loan & 0.12 & 0.1096 & 0.1257 & 0.1 & 0.0933 & 0.1033 & 0.1147 & 0.10951 \\
\hline $\begin{array}{l}\text { Average } \\
\text { capita }\end{array}$ & Salary/GNI per & 3.86 & 3.61 & 3.88 & 3.67 & 4.53 & 5 & 4.76 & 4.18714 \\
\hline \multicolumn{2}{|c|}{ Cost Per Borrower } & 9.4217 & 9.3936 & 11.7725 & 10.2307 & 10.3168 & 12.535 & 15.3684 & 11.2912 \\
\hline \multicolumn{2}{|c|}{ Cost Per Loan } & 9.2427 & 9.3186 & 11.652 & 10.0141 & 10.0433 & 12.22 & 14.6856 & 11.0252 \\
\hline
\end{tabular}

Source: MIX Market Database (2013)

\subsubsection{GB Efficiency over the Period of 2005-2011}

Table 7 shows the distribution of average efficiency of GB over the period of 2005-2011. The study found that the value for operating expense per loan portfolio is 0.11681 with the ratio of personnel expense per loan portfolio turning out at 0.07476 . Meanwhile, average salary to per GNI per capita stands at 4.01, accordingly. Cost per borrower and cost per loan values are at 12.3492 and 12.2277 , respectively.

Table 7. Distribution of efficiency of GB in Bangladesh (average value from 2005 to 2011)

\begin{tabular}{llllllllll}
\hline Indicators & \multicolumn{3}{c}{ Efficiency of GB } & & & & Average \\
& & 2005 & 2006 & 2007 & 2008 & 2009 & 2010 & 2011 & \\
\hline $\begin{array}{l}\text { Operating } \\
\text { Portfolio }\end{array}$ & Expenses/Loan & 0.126 & 0.112 & 0.1272 & 0.1087 & 0.1122 & 0.1184 & 0.1138 & 0.11681 \\
$\begin{array}{l}\text { Personnel } \\
\text { Portfolio }\end{array}$ & Expenses/Loan & 0.075 & 0.072 & 0.08 & 0.0734 & 0.0764 & 0.0757 & 0.0712 & 0.07476 \\
Average Salary/GNI per capita & 4.44 & 3.9 & 3.66 & 3.35 & 4.05 & 4.62 & 4.05 & 4.01 \\
Cost Per Borrower & 10.95 & 9.196 & 10.6454 & 10.3195 & 12.9536 & 15.989 & 16.3907 & 12.3492 \\
Cost Per Loan & 10.1 & 9.196 & 10.6454 & 10.3195 & 12.9536 & 15.989 & 16.3907 & 12.2277 \\
\hline
\end{tabular}

(Source: MIX Market database, 2013) 


\subsubsection{BURO BD Efficiency over the Period of 2005-2011}

Table 8 shows the distribution of average efficiency of BURO BD over the period of 2005-2011. The study found that the value for operating expense per loan portfolio is 0.15991 with the ratio of personnel expense per loan portfolio turning out at 0.1125 accordingly. Meanwhile, average salary to per GNI per capita stands at 2.50429 accordingly. Cost per borrower and cost per loan values are at 14.8283 and 13.3048 , respectively.

Table 8. Distribution of efficiency of BURO BD in Bangladesh (average value from 2005 to2011)

\begin{tabular}{|c|c|c|c|c|c|c|c|c|c|}
\hline \multirow{2}{*}{\multicolumn{2}{|c|}{ Indicators }} & \multicolumn{7}{|c|}{ Efficiency of BURO BD } & \multirow[t]{2}{*}{ Average } \\
\hline & & 2005 & 2006 & 2007 & 2008 & 2009 & 2010 & 2011 & \\
\hline $\begin{array}{l}\text { Operating } \\
\text { Portfolio }\end{array}$ & Expenses/Loan & 0.1392 & 0.1524 & 0.1678 & 0.1702 & 0.1636 & 0.1737 & 0.1525 & 0.15991 \\
\hline $\begin{array}{l}\text { Personnel } \\
\text { Portfolio }\end{array}$ & Expenses/Loan & 0.0954 & 0.1037 & 0.1168 & 0.1166 & 0.1135 & 0.1293 & 0.1122 & 0.1125 \\
\hline $\begin{array}{l}\text { Average } \\
\text { capita }\end{array}$ & Salary/GNI per & 2.79 & 2.78 & 2.52 & 2.61 & 2.31 & 2.44 & 2.08 & 2.50429 \\
\hline \multicolumn{2}{|c|}{ Cost Per Borrower } & 11.461 & 12.938 & 14.9998 & 15.794 & 15.9986 & 17.9252 & 14.6817 & 14.8283 \\
\hline \multicolumn{2}{|c|}{ Cost Per Loan } & 9.3137 & 11.006 & 13.2395 & 14.5849 & 14.9172 & 16.5458 & 13.5266 & 13.3048 \\
\hline
\end{tabular}

(Source: MIX Market database, 2013)

\subsubsection{TMSS Efficiency over the Period of 2005-2011}

Table 9 shows the distribution of average efficiency of GB over the period of 2005-2011. The study found that the value for operating expense per loan portfolio is 0.16563 with the ratio of personnel expense per loan portfolio turning out at 0.11777 accordingly. Meanwhile, average salary to per GNI per capita stands at 2.5 accordingly. Cost per borrower and cost per loan values are at 15.5597 and 15.1434 , respectively.

Table 9. Distribution of efficiency of TMSS in Bangladesh (average value from 2005 to 2011)

\begin{tabular}{|c|c|c|c|c|c|c|c|c|}
\hline \multirow[t]{2}{*}{ Indicators } & \multicolumn{7}{|c|}{ Efficiency of TMSS } & \multirow[t]{2}{*}{ Average } \\
\hline & 2005 & 2006 & 2007 & 2008 & 2009 & 2010 & 2011 & \\
\hline $\begin{array}{ll}\text { Operating } & \text { Expenses/Loan } \\
\text { Portfolio } & \end{array}$ & 0.178 & 0.1748 & 0.2121 & 0.1726 & 0.1455 & 0.1526 & 0.1238 & 0.16563 \\
\hline $\begin{array}{l}\text { Personnel Expenses/Loan } \\
\text { Portfolio }\end{array}$ & 0.1132 & 0.1065 & 0.1334 & 0.1332 & 0.1189 & 0.123 & 0.0962 & 0.11777 \\
\hline $\begin{array}{l}\text { Average Salary/GNI per } \\
\text { capita }\end{array}$ & 2.42 & 1.81 & 2.19 & 2.75 & 2.78 & 3.19 & 2.36 & 2.5 \\
\hline Cost Per Borrower & 11.928 & 12.517 & 16.339 & 14.8541 & 15.8086 & 20.4566 & 17.0148 & 15.5597 \\
\hline Cost Per Loan & 11.267 & 12.367 & 15.8631 & 14.539 & 15.3415 & 19.8539 & 16.772 & 15.1434 \\
\hline
\end{tabular}

Table 10. Distribution of overall efficiency of MFIs in Bangladesh (average value from 2005 to 2011)

\begin{tabular}{llllll}
\hline Efficiency of MFIs (average score from 2005 to 2011) & & & & \\
& ASA & BRAC & GB & BURO BD & TMSS \\
\hline Operating Expenses/Loan Portfolio & 0.11639 & 0.12651 & 0.11681 & 0.15991 & 0.166 \\
Personnel Expenses/Loan Portfolio & 0.10093 & 0.10951 & 0.07476 & 0.1125 & 0.118 \\
Average Salary/GNI per capita & 3.47857 & 4.18714 & 4.01 & 2.50429 & 2.5 \\
Cost Per Borrower & 10.1084 & 11.2912 & 12.3492 & 14.8283 & 15.56 \\
Cost Per Loan & 10.0884 & 11.0252 & 12.2277 & 13.3048 & 15.14 \\
Operational Self-Sufficiency & 1.92739 & 1.0759 & 1.60561 & 1.17539 & 1.13 \\
\hline
\end{tabular}

Source: MIX Market Database (2013) 


\subsubsection{MFIs Efficiency over the Period of 2005-2011}

Based on the findings and analysis, it is found that the average values for Operating Expenses/Loan Portfolio of ASA, GB BRAC, BURO Bangladesh and TMSS is 0.11639, $0.126510 .11681,0.15991$, and 0.166, respectively. Moreover, in terms of efficiency, TMSS has the highest proportion of operating expense to loan portfolio at 0.166 and ASA the lowest at 0.11639 , accordingly. Moreover, in the case of the average values for Personnel Expenses/Loan Portfolio of ASA, GB BRAC, BURO Bangladesh and TMSS is 0.10093, 0.10951, 0.07476, 0.1125 , and 0.118 , respectively. Moreover, in terms of efficiency, TMSS has the highest proportion of operating expense to loan portfolio at 0.166 and GB the lowest at 0.07476 , accordingly.

In terms of the average values for Average Salary/GNI per capita of ASA, GB BRAC, BURO Bangladesh, and TMSS is $3.47857,4.18714,4.01,2.50429$, and 2.5, respectively. Moreover, in terms of efficiency, BRAC has the highest proportion of operating expense to loan portfolio at 4.18714 and TMSS the lowest at 2.5, accordingly. Furthermore, in the case of the average values for Average Salary/GNI per capita of ASA, GB BRAC, BURO Bangladesh, and TMSS is 10.0884, 11.0252, 12.2277, 13.3048, and 15.14, respectively. Moreover, in terms of efficiency, TMSS has the highest proportion of operating expense to loan portfolio at 15.14 and ASA the lowest at 10.0884 , accordingly.

In terms of efficiency, ASA has the highest proportion of operating expense to loan portfolio at 0.12708 and GB the lowest at 0.11606. Moreover, in terms of Personnel Expenses to Loan Portfolio, ASA also has the highest score 0.1102 and GB has the lowest 0.07534 , respectively. However, in terms of Average Salary to GNI per capita, GB has the highest score 3.946 and BRAC has the lowest 4.368, respectively. On the other hand, for Cost per Borrower BRACK has the highest score 13.2597 and ASA has the lowest 4.368, respectively. This means that ASA, GB BRAC, BURO Bangladesh, and TMSS can be considered to be Operationally Self Sustainable.

\subsection{Regression Result of Determinants of OSS}

The estimated result of multiple regression analysis is also at a quite satisfactory level where the adjusted $\mathrm{R}^{2}$ is 0.80 and observed $R^{2}$ value is 0.73 , respectively. The value of adjusted $R^{2}$ revealed that there are good relationships with dependent variables and independent variables where all independent variables can explain about $73 \%$ of the operational self-sufficiency. On the other hand, the ANOVA table also reflects the goodness of model and F-test estimates that the regression is quite meaningful in the sense that the dependent variable is related to each specific explanatory variable.

Table 11. The distribution of regression result of OSS of MFIs in Bangladesh

\begin{tabular}{|c|c|c|c|c|c|}
\hline \multirow[t]{2}{*}{ Model } & \multicolumn{2}{|c|}{ Unstandardized Coefficients } & \multirow{2}{*}{$\begin{array}{l}\text { Standardized Coefficients } \\
\text { Beta }\end{array}$} & \multirow{2}{*}{$\mathrm{t}$} & \multirow{2}{*}{ Sig. } \\
\hline & B & Std. Error & & & \\
\hline (Constant) & 2.544 & 4.337 & & .587 & .563 \\
\hline YIELD & -.747 & 3.322 & -.034 & -.225 & .824 \\
\hline PPR & -1.162 & 7.477 & -.034 & -.155 & .878 \\
\hline DER & .015 & .032 & .084 & .479 & .636 \\
\hline CPB & .126 & .085 & .622 & 1.485 & .150 \\
\hline OER & -10.914 & 7.212 & -.444 & -1.513 & .143 \\
\hline LN_SIZE & $.083 * *$ & .032 & .366 & 2.617 & .015 \\
\hline LN_ALBPB & -1.395 & .935 & -.522 & -1.492 & .148 \\
\hline LN_Ages & $-.751 * * *$ & .228 & -.399 & -3.287 & .003 \\
\hline LN_NAB & $.401 * * *$ & .105 & .674 & 3.832 & .001 \\
\hline \multicolumn{6}{|c|}{ R-Squared 0.80} \\
\hline \multicolumn{6}{|c|}{ Adjusted R-Squared 0.73} \\
\hline \multicolumn{6}{|c|}{ F-statistic 11.264} \\
\hline Prob. (F-stat.) & & & & & \\
\hline
\end{tabular}

$* * *$ Significant at $1 \% ; * *$ Significant at $5 \%$

The linear relation of the model is highly significant where the $\mathrm{p}$ value for the $\mathrm{F}$ is less than $0.001 \%$ level. Furthermore, the estimated coefficient also denoted from the model that most of the variables are significantly related at the 0.01 and 0.05 levels, which is significantly different than zero. 
Moreover, the regression result also reveals that Size of MFIs (SIZE) Cost Per Borrower (CPB) and Personnel Productivity Ratio (PPR) positively explain the financial self-sufficiency of MFIs in Bangladesh. On the other hand, variables of average Loan Balance per Borrowers (ALBPB), Age of MFIs (AGE) Debt to Equity Ratio (DER), Operating Expense Ratio (OER), and Number of active borrowers (NAB) have a negative effect on the financial self-sufficiency at a significant level of FSS of MFIs in Bangladesh whereas the Yield on Gross loan Portfolio (YIELD) of MFIs is also positive but not at a significant level.

Table 12. The distribution of hypothesis status of OSS of MFIs in Bangladesh

\begin{tabular}{|c|c|c|c|}
\hline Hypothesis & B & Sig. & Status \\
\hline $\begin{array}{l}\text { H1b: There is a significant positive relationship on the yield on gross loan } \\
\text { portfolio of microfinance institutions with operational self-sufficiency }\end{array}$ & -0.747 & 0.824 & Rejected \\
\hline $\begin{array}{l}\text { H2b: There is a positive significant relationship between Size of microfinance } \\
\text { institutions and operational self-sufficiency. }\end{array}$ & -1.162 & 0.878 & Rejected \\
\hline $\begin{array}{l}\text { H3b: There is a positive significant relationship between personnel productivity } \\
\text { ratio and operational self-sufficiency. }\end{array}$ & 0.015 & 0.636 & Accepted \\
\hline $\begin{array}{l}\text { H4b: There is a negative significant relationship between debt to equity ratio of } \\
\text { microfinance institutions with operational self-sufficiency. }\end{array}$ & 0.126 & 0.15 & Rejected \\
\hline H5b: Cost per borrower is negatively related and operational self-sufficiency. & 0.401 & 0.001 & Rejected \\
\hline $\begin{array}{l}\text { H6b: There is a significant positive relationship between average loan balances } \\
\text { per borrower to operational self-sufficiency. }\end{array}$ & 0.083 & 0.015 & Accepted \\
\hline $\begin{array}{l}\text { H7b: Age of a microfinance institution is significantly and positively related to } \\
\text { operational self-sufficiency. }\end{array}$ & -1.395 & 0.148 & Rejected \\
\hline $\begin{array}{l}\text { H8b: There is significant positive relationship between number of active } \\
\text { borrowers and operational self-sufficiency. }\end{array}$ & -0.751 & 0.003 & Rejected \\
\hline $\begin{array}{l}\text { H9b: There is a negative significant relationship between operating expense } \\
\text { ratio and operational self-sufficiency. }\end{array}$ & -10.914 & 0.143 & Accepted \\
\hline
\end{tabular}

Finally, the study found that estimated result of multiple regression analysis is also at a quite satisfactory level where the adjusted $R^{2}$ is 0.73 and observed $R^{2}$ value is 0.80 , respectively. The value of adjusted $R^{2}$ revealed that there are good relationships with dependent variables and independent variables where all independent variables can explain about $73 \%$ of the financial self-sufficiency. Moreover, the study recommends for policy considerations of the successful and effective operation of microfinance programs by simplifying distribution of loan, improving yield on gross loan portfolio, personnel productivity and reducing of borrowing funds from the donors, reducing operating cost, utilizing resources to generate financial revenue and focus on increasing the value of their total assets in Bangladesh.

\section{Conclusion and Recommendations}

As this paper aims to measure the performance of operational self-sufficiency and its determinants of Microfinance Institutions (MFIs) and compared their positions in Bangladesh. Based on the findings and analysis, it is found that the average values for Operating Expenses/Loan Portfolio of ASA, GB BRAC, BURO Bangladesh and TMSS is $0.11639,0.126510 .11681,0.15991$, and 0.166 , respectively. Moreover, in terms of efficiency, TMSS has the highest proportion of operating expense to loan portfolio at 0.166 and ASA the lowest at 0.11639 , accordingly. Moreover, in the case of the average values for Personnel Expenses/Loan Portfolio of ASA, GB BRAC, BURO Bangladesh and TMSS is 0.10093, 0.10951, 0.07476, 0.1125, and 0.118, respectively. Moreover, in terms of efficiency, TMSS has the highest proportion of operating expense to loan portfolio at 0.166 and GB the lowest at 0.07476 , accordingly.

In terms of the average values for Average Salary/GNI per capita of ASA, GB BRAC, BURO Bangladesh, and TMSS is 3.47857, 4.18714, 4.01, 2.50429, and 2.5, respectively. Moreover, in terms of efficiency, BRAC has the highest proportion of operating expense to loan portfolio at 4.18714 and TMSS the lowest at 2.5, accordingly. Furthermore, in the case of the average values for Average Salary/GNI per capita of ASA, GB BRAC, BURO Bangladesh, and TMSS is $10.0884,11.0252,12.2277,13.3048$, and 15.14, respectively. Moreover, in terms of 
efficiency, TMSS has the highest proportion of operating expense to loan portfolio at 15.14 and ASA the lowest at 10.0884, accordingly. In terms of efficiency, ASA has the highest proportion of operating expense to loan portfolio at 0.12708 and GB the lowest at 0.11606. Moreover, in terms of Personnel Expenses to Loan Portfolio, ASA also has the highest score 0.1102 and GB has the lowest 0.07534 , respectively. However, in terms of Average Salary to GNI per capita, GB has the highest score 3.946 and BRAC has the lowest 4.368, respectively. On the other hand, for Cost per Borrower BRACK has the highest score 13.2597 and ASA has the lowest 4.368, respectively. This means that ASA, GB BRAC, BURO Bangladesh, and TMSS can be considered to be Operationally Self Sustainable.

The study also found that estimated result of multiple regression analysis is also at a quite satisfactory level where the adjusted $R^{2}$ is 0.73 and observed $R^{2}$ value is 0.80 , respectively. The value of adjusted $R^{2}$ revealed that there are good relationships with dependent variables and independent variables where all independent variables can explain about $73 \%$ of the financial self-sufficiency. Moreover, the study recommends for policy considerations of the successful and effective operation of microfinance programs by simplifying distribution of loan, improving yield on gross loan portfolio, personnel productivity and reducing of borrowing funds from the donors, reducing operating cost, utilizing resources to generate financial revenue and focus on increasing the value of their total assets in Bangladesh.

Finally, regression result also reveals that Size of MFIs (SIZE) Cost Per Borrower (CPB) and Personnel Productivity Ratio (PPR) positively explain the financial self-sufficiency of MFIs in Bangladesh. On the other hand, variables of average Loan Balance per Borrowers (ALBPB), Age of MFIs (AGE) Debt to Equity Ratio (DER), Operating Expense Ratio (OER), and Number of active borrowers (NAB) have a negative effect on the financial self-sufficiency at a significant level of FSS of MFIs in Bangladesh whereas the Yield on Gross loan Portfolio (YIELD) of MFIs is also positive but not at a significant level.

\section{References}

Annim, S. K. (2012). Microfinance efficiency: Trade-offs and complementarities between the objectives of microfinance institutions and their performance perspectives. European Journal of Development Research, 24(5), 788-807. http://dx.doi.org/10.1057/ejdr.2011.60

Arnone, M., Pellegrini, C. B., Messa, A., Pellegrini, L., \& Sironi, E. (2012). Microfinance institutions in Africa, Asia, and Latin America: An empirical analysis of operational efficiency, institutional context and costs. International Journal of Economic Policy in Emerging Economies, 5(3), 255-271. http://dx.doi.org/10.1504/ IJEPEE.2012.051366

Bassem, B. S. (2008). Efficiency of microfinance institutions in the mediterranean: An application of DEA. Transition Studies Review, 15(2), 343-354. http://dx.doi.org/10.1007/s11300-008-0012-7

Borbora, G. K. S. S. (2011). Is Microfinance Outreach Sustainable? A Case of Microfinance Institution Model in India. Paper presented at the Second European Research Conference on Microfinance.

CGAP. (2003). Microfinance Consensus Guidelines. Washington: CGAP/The World Bank Group.

Gregoire, J. R., \& Ramírez, T. O. (2006). Cost efficiency of microfinance institutions in Peru: A stochastic frontier approach. Latin American Business Review, 7(2), 41-70. http://dx.doi.org/10.1300/J140v07n02_03

Gutiérrez-Nieto, B., Serrano-Cinca, C., \& Mar Molinero, C. (2007). Microfinance institutions and efficiency. Omega, 35(2), 131-142. http://dx.doi.org/10.1016/j.omega.2005.04.001

Gutiérrez-Nieto, B., Serrano-Cinca, C., \& Mar Molinero, C. (2009). Social efficiency in microfinance institutions. Journal of the Operational Research Society, 60(1), 104-119. http://dx.doi.org/10.1057/ palgrave.jors. 2602527

Hartarska, V., \& Mersland, R. (2012). Which Governance Mechanisms Promote Efficiency in Reaching Poor Clients? Evidence from Rated Microfinance Institutions. European Financial Management, 18(2), 218-239. http://dx.doi.org/10.1111/j.1468-036X.2009.00524.x

Hartarska, V., Shen, X., \& Mersland, R. (2013). Scale economies and input price elasticities in microfinance institutions. Journal of Banking and Finance, 37(1), 118-131. http://dx.doi.org/10.1016/j.jbankfin.2012.08. 004

Hermes, N., Lensink, R., \& Meesters, A. (2009). Financial development and the efficiency of microfinance institutions.

Hermes, N., Lensink, R., \& Meesters, A. (2011). Outreach and Efficiency of Microfinance Institutions. World 
Development, 39(6), 938-948. http://dx.doi.org/10.1016/j.worlddev.2009.10.018

Hudon, M., \& Traca, D. (2011). On the Efficiency Effects of Subsidies in Microfinance: An Empirical Inquiry. World Development, 39(6), 966-973. http://dx.doi.org/10.1016/j.worlddev.2009.10.017

Kinde, B. A. (2012). Financial Sustainability of Microfinance Institutions (MFIs) in Ethiopia. European Journal of Business and Management, 4(15), 10.

Martínez-González, A. (2008). Technical Efficiency Of Microfinance Institutions: Evidence From Mexico. The Ohio State University.

Mixmarket. (2013). Retrieved from http://www.mixmarket.org/mfi/grameen-bank

Thapa, G. (2007). Sustainability and Governance of MFIs. Rome: International Fund for Agricultural Development.

Woldeyes, M. T. (2012). Determinants of Operational and Financial Self-Sufficiency: An Empirical Evidence of Ethiopian Microfinance Institutions. Addis Ababa University.

\section{Copyrights}

Copyright for this article is retained by the author(s), with first publication rights granted to the journal.

This is an open-access article distributed under the terms and conditions of the Creative Commons Attribution license (http://creativecommons.org/licenses/by/3.0/). 